\title{
УДК 631.171:631.53.027.3:633/635
}

\section{ББК 41.3}

B 29

Редактор: С.А. Трищенко

Рецензенты: профессор, доктор технических наук А.Г. Пастухов (Белгородская государственная сельскохозяйственная академия имени В.Я.Горина);

профессор, кандидат технических наук А. А. Виноградов (Белгородский государственный технологический университет имени В.Г. Шухова).

\section{В 29 Вендин С.В.}

Теория и математические методы анализа тепловых процессов при СВЧ обработке семян : монография / С.В. Вендин. - Москва; Белгород: ОАО «Центральный коллектор библиотек «БИБКОМ», 2016.- 143 с. ISBN 978-5-905563-56-0

В монографии изложены теория и математические методы анализа процессов термической обработки семян в высокочастотном электромагнитном поле.

Представлены решения задачи теплопроводности в многослойных средах и рабочие математические модели, включающие исследование СВЧ нагрева семян при дезинсекции, дезинфекции и предпосевной стимуляции, а также примеры применения результатов теоретических исследований для расчета технологических и конструктивных параметров СВЧ оборудования.

Монография предназначена для научных и инженерно-технических работников, преподавателей, аспирантов и студентов по специальности «Электротехнологии и электрооборудование в АПК».

(C) Вендин С.В., 2016

(C) ОАО «ЦКБ «БИБКОМ», 2016 


\section{СОДЕРЖАНИЕ.}

Стр.

ВВЕДЕНИЕ......................................................

ОБЩАЯ ХАРАКТЕРИСТИКА ПРОБЛЕМЫ......................

1.1 Современные технологические приемы дезинсекции, дезинфекции и предпосевной обработки семян....................

1.2 Специфические особенности применения электромагнитных полей сверхвысокой частоты для дезинсекции, дезинфекции и предпосевной обработки семян.................................

1.3 Физическая модель процесса термической обработки семян в электромагнитном поле СВЧ.

1.4 Выводы......................................................

2 ТЕОРИЯ И М МТЕМАТИЧЕСКИЕ ИССЛЕДОВАНИЯ ПРОЦЕССА НАГРЕВА СЕМЯН В ЭМП СВЧ.

2.1 Общая постановка задачи........................................

2.2 Решение задачи СВЧ нагрева одномерных многослойных объектов.................................................

2.2.1 Решение общей краевой задачи уравнения теплопроводности для одномерных многослойных объектов при неоднородных граничных условиях третьего рода...............................

2.2.2 СВЧ нагрев одномерных многослойных объектов при стационарных неоднородных граничных условиях третьего рода и независимости интенсивности поглощения СВЧ энергии от

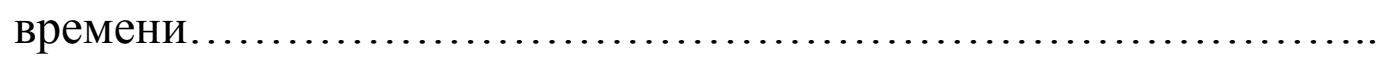

2.2.3 СВЧ нагрев одномерных многослойных объектов при стационарных неоднородных граничных условиях третьего рода и при периодическом во времени поглощении энергии (импульсный СВЧ нагрев) .....................................

2.2.4 Рабочие формулы записи аналитического решения задач СВЧ нагрева для многослойных сферических, цилиндрических и плоскостных объектов.

2.3 Математическая модель исследования СВЧ нагрева при дезинсекции, дезинфекции и предпосевной стимуляции............

2.3.1 Экспериментальная проверка адекватности математической модели СВЧ нагрева семени..................................

2.4 Численный эксперимент и анализ СВЧ нагрева семени при СВЧ дезинсекции, дезинфекции и предпосевной стимуляции

2.5 Выводы и технологические рекомендации.........................

3 ПРИМЕНЕНИЕ РЕЗУЛЬТАТОВ ТЕОРЕТИЧЕСКИХ ИССЛЕДОВАНИЙ ДЛЯ РАСЧЕТА ТЕХНОЛОГИЧЕСКИХ И КОНСТРУКТИВНЫХ ПАРАМЕТРОВ СВЧ ОБОРУДОВАНИЯ..................................................

3.1 Определение режимных параметров термической СВЧ обработки семян при недостатке исходных данных 
3.2 Расчет технологических параметров при СВЧ обработке объема семян в объемном резонаторе или в радиогерметичной камере под излучателем........................................... 106

3.3 Расчет технологических параметров при СВЧ обработке семян в слое на конвейерной ленте под излучателем......................

3.4 Расчет основных технологических и конструктивных параметров при СВЧ обработке потока семян в камере взаимодействия резонаторного типа......................................... 111

3.5 Выводы....................................................... 121

ЗАКЛЮЧЕНИЕ................................................. 122

БИБЛИОГРАФИЧЕСКИЙ СПИСОК........................... 124 